\title{
MENINGKATKAN KONSENTRASI, KEMANDIRIAN DAN HASIL BELAJAR PENJUMLAHAN BILANGAN BULAT MELALUI MEDIA DOTMETI PADA SISWA ABK KELAS IV SDN INKLUSI SUMBERSARI I MALANG
}

\author{
Tri Istiningsih \\ e-mail: tri.istiningsih@yahoo.com
}

\begin{abstract}
The purpose of this study is to describe the use and application of DOTMETI media in increasing concentrations, Independence, and Learning Outcomes in the addition of ABK students in class IV integers SDN Sumbersari 1 Malang. This study used a qualitative approach. This research is Classroom Action Research. The subjects of this study were fourth grade students at SDN ABK Sumbersari 1 year 2012/2013 Malang. The results of this study indicate DOTMETI media can improve learning Mathematics Elementary School fourth grade students ABK Sumbersari 1 Malang. This is demonstrated by the increasing concentration and independence in learning Mathematics 1 to 4 meetings achieve a good level of success of the classical. Increased learning outcomes shown in the average value of each meeting increased.
\end{abstract}

\begin{abstract}
Abstrak: Penelitian ini bertujuan untuk mendeskripsikan penggunaan dan penerapan media DOTMETI dalam meningkatkan Konsentrasi, Kemandirian, dan Hasil Belajar siswa ABK dalam penjumlahan bilangan bulat di kelas IV SDN Sumbersari 1 Malang. Penelitian ini menggunakan pendekatan kualitatif. Jenis penelitian ini adalah Penelitian Tindakan Kelas (PTK). Subyek penelitian ini adalah siswa ABK kelas IV SDN Sumbersari 1 tahun 2012/2013 Malang. Hasil penelitian ini menunjukkan media DOTMETI dapat meningkatkan pembelajaran Matematika siswa ABK kelas IV SDN Sumbersari 1 Malang. Hal ini ditunjukkan dengan meningkatnya konsentrasi dan kemandirian dalam pembelajaran Matematika pertemuan 1 sampai 4 mencapai taraf keberhasilan klasikal baik. Meningkatnya hasil belajar ditunjukkan pada nilai rata-rata setiap pertemuan yang meningkat.
\end{abstract}

Kata Kunci: DOTMETI, konsentrasi, kemandirian, hasil belajar, siswa ABK

Dewasa ini Pendidikan sudah menjadi kebutuhan masyarakat Indonesia. Pendidikan juga sudah menjadi status sosial masyarakat. Proses pembelajaran di jenjang pendidikan Sekolah Dasar (SD) merupakan pondasi awal dari semua jenjang tingkat pendidikan yang ada serta merupakan wahana belajar formal bagi siswa yang dijadikan sebagai bekal utama untuk melanjutkan ke tingkat jenjang pendidikan yang lebih tinggi, juga wahana bagi siswa untuk dapat mengembangkan menjadi manusia seutuhnya.
Kebijakan pemerintah dalam penuntasan Wajib Belajar Pendidikan Dasar Sembilan Tahun disemangati oleh seruan Internasional Education For All (EFA) yang dikumandangkan UNESCO sebagai kesepakatan global hasil World Education Forum di Dakar, Sinegal tahun 2000, penuntasan EFA diharapkan tercapai pada Tahun 2015.

Seruan ini senafas dengan semasemangat dan jiwa Pasal 31 UUD 1945 tentang hak setiap warga negara untuk memperoleh pendidikan dan Pasal 32 UU Sisdiknas Nomor 20 Tahun 2003 tentang Sistem Pendidikan Nasional ya- 
ng mengatur mengenai pendidikan khusus dan pendidikan layanan khusus.

Sedang pemerataan kesempatan belajar bagi anak berkebutuhan khusus dilandasi pernyataan Salamanca tahun 1994. Pernyataan Salamanca ini merupakan perluasan tujuan Education Fol All dengan mempertimbangkan pergeseran kebijakan mendasar yang diperlukan untuk menggalakkan pendekatan pendidikan inklusif. Melalui pendidikan inklusif ini diharapkan sekolah-sekolah reguler dapat melayani semua anak, termasuk mereka yang memiliki kebutuhan pendidikan khusus. Di Indonesia melalui Keputusan Menteri Pendidikan dan Kebudayaan No. 002/U/1986 telah dirintis pengembangan sekolah penyelenggaraan pendidikan inklusif yang melayani Penuntasan Wajib Belajar bagi peserta didik yang berkebutuhan khusus.

SD Sumbersari 1 adalah salah satu dari sekian banyak SD inklusi yang berada di Indonesia, khususnya di kota Malang. Jawa Timur yang berusaha memberikan layanan Inklusif untuk semua peserta didik tak terkecuali siswa ABK. Pada jenjang kelas IV SDN Inklusi Sumbersari 1 saat ini memiliki memiliki 21 siswa yang terdiri dari 16 siswa reguler dan 5 siswa ABK. Dari kelima siswa ABK terassesmen, 3 siswa auties, 1 siswa ADHD dan 1 siswa tunarungu. Berdasarkan kondisi tersebut guru harus dapat mengkondisikan pembelajaran yang efektif untuk mendukung penguasaan dan pemahaman materi serta peningkatan nilai hasil belajar.

Berdasarkan hasil observasi di kelas IV SDN Sumbersari 1 Malang, ditemukan beberapa permasalahan khususnya dalam kegiatan pembelajaran Matematika yang masih berpusat pada guru. Dalam kegiatan pembelajaran guru cenderung menggunakan metode diskusi, namun guru masih banyak terlibat dalam menjelaskan materi. Seharusnya dalam kegiatan diskusi, siswa harus lebih berperan aktif dalam kegiatan pembelajaran. Masih banyak siswa yang ramai sendiri, mereka tidak fokus dalam pengerjaan tugas kelompoknya. Apalagi bagi kelompok yang berada di belakang, mereka cenderung ramai sendiri bercanda dengan teman anggota kelompoknya.

Tidak semua mata pelajaran dipahami dan dicapai dengan nilai yang maksimal,khususnya pelajaran matematika. Dari data yang di peroleh, masih ada $40 \%$ siswa yang mempunyai nilai di bawah KKM.

Siswa di kelas IV SDN Sumbersari 1 Malang ini mempunyai kemampuan dalam hal akademik yang heterogen (berbeda-beda). Jumlah perbandingan antara siswa yang mempunyai kemampuan akademik tinggi dengan yang mem punyai kemampuan akademik yang kurang, lebih banyak jumlah siswa yang mempunyai akademik kurang. Hal ini merupakan suatu masalah sebagai tantangan bagi guru yang harus diselesaikan untuk mengambil jalan keluar, agar da-, lam kegiatan pembelajaran dapat berjalan secara maksimal khususnya dalam pembelajaran Matematika bagi guru kelas IV SDN Sumbersari 1 Malang.

Dari uraian diatas dapat dinyatakan bahwa guru mempunyai peranan penting dalam kemajuan dunia pendidikan. Salah satunya adalah dalam pemilihan dan penggunaan media pembelajaran. Hal ini sangat diperlukan bagi guru untuk dapat menciptakan pembelajaran yang inovatif, kreatif, dan dapat menarik mina serta motivasi siswa. Dengan demikian diharapkan dapat meningkatkan keaktifan siswa dalam mengikuti proses pembelajaran dan meningkatkan pemahaman serta meningkatkan nilai hasil belajar

Media pembelajaran DOTMETI adalah media yang mudah didapat dan harganya relatif murah. Media ini tersedia dengan beragam warna. Dalam peng- 
gunaannya dapat kita pilih dua warna untuk mewakili bilangan positif dan negatif (contoh warna putih untuk bilangan positif dan warna merah untuk bilangan negatif). Selain itu media ini sangat mudah penggunaannya baik oleh siswa reguler maupun siswa $\mathrm{ABK}$

Berdasarkan uraian diatas serta izin kepala sekolah, maka peneliti perlu melakukan Penelitian Tindakan Kelas (PTK) dengan judul "Meningkatkan Konsentrasi, Kemandirian dan Hasil Belajar Penjumlahan Bilangan Bulat melalui Media DOTMETI pada Siswa ABK Kelas IV SDN Inklusi Sumbersari I Malang"

\section{METODE PENELITIAN}

Pendekatan penelitian yang digunakan dalam penelitian ini adalah pendekatan kualitatif yang bersifat alami apa adanya, dan tidak ada manipulasi data. Menurut Moleong, (dalam Khoiriyah, 2010: 33) "Peneliti kualitatif berusaha berinteraksi dengan subyek penelitinya secara alamiah. Penelitian dimaksudkan untuk mendeskripsikan peristiwa-peristiwa sebagaimana yang terjadi secara alami melalui pengumpulan data yang kemudian data tersebut dipaparkan dalam bentuk kalimat (deskriptif)".

Jenis penelitian yang digunakan adalah Penelitian Tindakan Kelas (PTK). "PTK adalah proses investigasi terkendali untuk menemukan dan memecahkan masalah pembelajaran di kelas, proses pemecahan masalah tersebut dilakukan secara bersiklus, dengan tujuan untuk meningkatkan kualitas pembelajaran dan hasil pembelajaran di kelas tertentu" (Akbar, 2010:26)

Penelitian Tindakan Kelas (PTK) ini dilaksanakan oleh guru kelas IV SDN Sumbersari 1 Malang, yang berperan sebagai pelaksana pembelajaran dan seka- ligus sebagai peneliti, serta guru pendamping khusus yang peran sebagai observer

Penelitian ini direncanakan dalam dua siklus. Karena dalam Kompetensi Dasar (KD) "Penjumlahan bilangan bulat" terdapat dua indikator yaitu " penjumlahan bilangan bulat positif dan positif, penjumlahan bilangan bulat negatif dan negatif, dan "penjumlahan bilangan bulat positif dan negatif serta sebaliknya, sehingga siklus 1 meneliti tentang "penerapan dan penggunaan media DOTMETI untuk operasi penjumlahan bilangan bulat sejenis, dan siklus 2 meneliti tentang "penerapan penggunaan media DOTMETI dalam operasi penjumlahan bilangan bulat tak sejenis.

Masing-masing siklus melalui 4 tahapan yang diadaptasi dari model Kemmis dan Taggart, yaitu (1) perencanaan tindakan, (2) pelaksanaan tindakan, (3) observasi dan evaluasi, dan (4) refleksi.

Pengumpulan data tentang penerapan penggunaan media DOTMETI, dikumpulkan dengan instrumen sebagai berikut: (1) lembar observasi, digunakan untuk mengumpulkan data tentang penerapan penggunaan media DOTMETI dalam pembelajaran Matematika, (2) soal tes tertulis, digunakan untuk mengetahui data tentang hasil belajar Matematika dengan menerapan penggunaan media DOTMETI dan (3) dokumentasi (foto), digunakan untuk melengkapi data serta mendapatkan gambaran atau bukti kongkrit kegiatan di kelas.

Untuk mengumpulkan data tentang penerapan penggunaan media DOTMETI, dikumpulkan dengan menganalisis sebagai berikut: (1) penerapan penggunaan media DOTMETI dalam pembelajaran Matematika, (2) konsentrasi dan kemandirian belajar Matematika melalui penerapan penggunaan media DOTMETI, dan (3) hasil belajar Matematika me- 
lalui penerapan penggunaan media DOTMETI.

Analisis data dalam penelitian ini adalah sebagai berikut. (1) pengumpulan data; pengumpulan data dilakukan secara langsung dengan menggunakan pedoman observasi, tes tertulis, dan foto digital, (2) klasifikasi data; klasifikasi data dilakukan untuk mengelompokkan jenis data sesuai dengan komponen-komponen penelitian, antara lain: (a) kelompok data tentang pelaksanaan pembelajaran, (b) data tentang konsentrasi dan kemandirian belajar siswa, dan (c) data tentang hasil belajar siswa, (3) reduksi data; yaitu proses merangkum dan menyeleksi data yang terkumpul dan terekam dalam lembar observasi, hasil soal tes tertulis, dan dokumentasi berupa foto, (4) penyajian data; penyajian data dituangkan dalam bentuk naratif yang dikemas secara sistematis sehingga memudahkan penarikan kesimpulan, (5) penarikan kesimpulan; merupakan pemberian makna dan arti dari data yang telah direduksi dan menguji.

\section{HASIL DAN PEMBAHASAN}

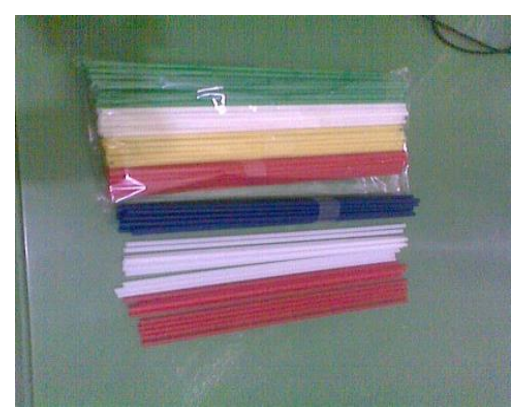

Berdasarkan hasil tes terhadap
siswa yang dilakukan setelah
pembelajaran pada siklus 1 pertemuan 1,
diperoleh data yang bervariasi mengenai
penguasaan siswa terhadap kompetensi
dasar "Penjumlahan Bilangan Bulat".
Dari data yang ada, dinyatakan
bahwa dari 21 siswa mempunyai ke- mampuan yang bervariasi. Dari data tersebut diperoleh gambaran sebagai berikut. (1) Terdapat 8 siswa yang mencapai taraf hasil belajar rentang skor antara 6180. Hal ini berarti dalam taraf keberhasilan baik. (2) Terdapat 5 siswa yang mencapai taraf hasil belajar rentang skor 41-60. Hal ini berarti dalam taraf keberhasilan cukup. (3) Terdapat 3 siswa yang mencapai taraf hasil belajar rentang skor 21-40. Hal ini berarti dalam taraf keberhasilan kurang. (4) Terdapat 5 siswa yang mencapai taraf hasil belajar rentang skor 0-20. Hal ini berarti dalam taraf keberhasilan kurang sekali.

Selanjutnya dari hasil pengamatan yang dilakukan pada pertemuan kedua sudah terdapat banyak kemajuan pada siswa kelas IV pada umumnya dan siswa ABK pada khususnya. Dari data tersebut diperoleh gambaran sebagai berikut. (1) Terdapat 8 siswa yang mencapai taraf hasil belajar rentang skor antara 81-100. Hal ini berarti dalam taraf keberhasilan baik sekali. (2) Terdapat 8 siswa yang mencapai taraf hasil belajar rentang skor 61-80. Hal ini berarti dalam taraf keberhasilan baik. (3) Terdapat 5 siswa yang mencapai taraf hasil belajar rentang skor 41-60. Hal ini berarti dalam taraf keberhasilan cukup.

Pertemuan selanjutnya dilanjutkan pada pertemuan ke satu siklus ke dua. Pertemuan ini diperoleh gambaran sebagai berikut: (1) Terdapat 10 siswa yang mencapai taraf hasil belajar rentang skor antara 81-100. Hal ini berarti dalam taraf keberhasilan baik sekali. (2) Terdapat 8 siswa yang mencapai taraf hasil belajar rentang skor 61-80. Hal ini berarti dalam taraf keberhasilan baik, (3) Terdapat 3 siswa yang mencapai taraf hasil belajar rentang skor 41-60. Hal ini berarti dalam taraf keberhasilan cukup.

Pada pertemuan kedua siklus ke dua telah mengalami kemajuan yang memuaskan dimana gambaran data sebagai 
berikut: (1) Terdapat 12 siswa yang mencapai taraf hasil belajar rentang skor antara 81-100. Hal ini berarti dalam taraf keberhasilan baik sekali. (2) Terdapat 6 siswa yang mencapai taraf hasil belajar rentang skor 61-80. Hal ini berarti dalam taraf keberhasilan baik. (3) Terdapat 3 siswa yang mencapai taraf hasil belajar rentang skor 41-60. Hal ini berarti dalam taraf keberhasilan cukup. Hal ini membuktikan bahwa dari siklus satu ke siklus dua terjadi peningkatan hasil belajar siswa mengalami peningkatan.

Tingkat konsentrasi siswa dalam pembelajaran penjumlahan bilangan bulat adalah pertemuan $1(51,56 \%)$, pertemuan $2(59,37 \%)$, pertemuan $3(86,17 \%)$ dan pertemuan $4(89,13 \%)$. Dari data diatas terlihat tingkat konsentrasi dan kemandirian siswa kelas IV selalu mengalami peningkatan.

Peningkatan konsentrasi dan kemandirian siswa ABK kelas IV SDN Sumbersari 1 Malang juga mengalami peningkatan walaupun tidak terlalu mencolok. Hal ini terlihat pada pertemuan 1 $(29,68 \%)$, pertemuan $2(45,31 \%)$, pertemuan $3(60.93 \%)$, pertemuan $4(64,06-$ $\%)$.

\section{KESIMPULAN}

Sesuai dengan rumusan masalah dan tujuan penelitian secara umum setelah melakukan kegiatan penelitian tindakan kelas yang berjudul "Meningkatkan Konsentrasi, Kemandirian dan Hasil Belajar Penjumlahan Bilangan Bulat melalui Media DOTMETI pada siswa ABK Kelas IV SDN Inklusi Sumber Sari I Malang dapat disimpulkan sebagai berikut :

Bentuk peningkatan konsentrasi dan kemandirian yang dicapai pada siswa kelas IV SDN Sumbersari 1 Malang dalam pembelajaran penjumlahan bila- ngan bulat adalah pertemuan $1(51,56 \%)$, pertemuan $2(59,37 \%)$, pertemuan $3(86$, $17 \%)$ dan pertemuan $4(89,13 \%)$. Dari data diatas terlihat tingkat konsentrasi dan kemandirian siswa kelas IV selalu mengalami peningkatan.

Peningkatan konsentrasi dan kemandirian siswa ABK kelas IV SDN Sumbersari 1 Malang juga mengalami peningkatan walaupun tidak terlalu mencolok. Hal ini terlihat pada pertemuan 1 $(29,68 \%)$, pertemuan $2(45,31 \%)$, pertemuan $3(60.93 \%)$, pertemuan $4(64,06-$ $\%)$.

Hasil belajar siswa juga mengalami peningkatan seperti nampak pada pertemuan $1(55,83 \%)$, pertemuan $2(82,86$ $\%$ ), pertemuan $3(86,67 \%)$, pertemuan 4 $(88,57 \%)$.

Dari data diatas terlihat kenaikan yang signifikan tingkat Konsentrasi, Kemandirian dan Hasil belajar siswa klas IV SDN Inklusi Sumbersari I pada umumnya dan pada siswa ABK pada khususnya, setelah menerapkan penggunaan media “ DOTMETI"dalam pembelajaran penjumlahan bilangan bulat.

Media DOTMETI selain memiliki kelebihan yang telah dipaparkan di atas juga dapat digunakan untuk pembelajaran Matematika pada Kompetensi Dasar "Membandingkan pecahan Sederhana Dan Penjumlahan Pecahan Sederhana". Setelah penggunaannya sebagai media pembelajaran terlaksana, media DOTMETI bisa dirangkai menjadi taplak meja yang cantik.

\section{DAFTAR PUSTAKA}

Abimanyu, Soli, Dkk. 2009. Strategi Pembelajaran. Jakarta: Departemen Pendidikan nasional.

Akbar, Sa'dun. 2010. Prosedur Penyusunan Laporan dan Artikel PTK. Yogyakarta: Cipta Media. 
31 Jurnal Pemikiran dan Pengembangan SD, Jilid 1, Nomor 2, September 2013, hlm. 26-31

Akbar, S. \& Faridatuz, L. 2009. Prosedur Penyusunan Laporan dan Artikel Hasil Penelitian Tindakan Kelas. Yogyakarta: Cipta Media Aksara

Alimin, Z. 2010. Makalah Seminar Nasional: Reorientasi Pendidikan Khusus/PLB ke Pendidikan Kebutuhan Khusus Sebagai Usaha Mencapai Pendidikan untuk Semua. Malang: UM.

Arsyad, Azhar. 2009. Median Pembelajaran. Jakarta: PT. Raja Grafindo Persada.

Depdiknas. 2004. Penelitian Tindakan Kelas. Jakarta: Depdiknas Dikti.

Putra, P. Yovan. 2008. Memori dan Pembelajaran Efektif. CV Yrama Widya

Sudjana, Nana. 2005. Penilaian Hasil Proses Belajar Mengajar. PT. Remaja Rosdakarya: Bandung. 